\title{
The role and importance of financial results in the effective management of an agricultural enterprise
}

\author{
Sergey Yekimov ${ }^{1, *}$, Anastasiia Poltorak ${ }^{2}$, Viacheslav Dereza ${ }^{3}$, Ievgen Buriak $^{4}$, and Vladimir \\ Purtov ${ }^{5}$ \\ ${ }^{1}$ Publishing House "Education and Science", Olstynska 607/1, 18100 Praha 8, Czech Republic \\ ${ }^{2}$ Mykolayiv National Agrarian University, st. Georgy Gongadze, 9, 54000 Nikolaev, Ukraine \\ ${ }^{3}$ Oles Honchar Dnipro National University, Gagarin Avenue, 72, 49000 Dnipro, Ukraine \\ ${ }^{4}$ Kremenchuk Mykhailo Ostrohradskyi National University, Pervomaiskaya Street, 20, 39600 \\ Kremenchuk, Ukraine \\ ${ }^{5}$ V. N. Karazin Kharkiv National University, Nezalezhnosti avenue, 6, 61000 Kharkiv, Ukraine
}

\begin{abstract}
Currently, in all regions of Republic of Belarus much attention is paid to improving the functioning of agricultural enterprises. Due to the fact that their level of liquidity and profitability to a large extent becomes dependent on the current state of the state food market, its ability to meet the needs of legal entities and the population and the ability to purchase high-quality agricultural products have a great influence on agricultural export growth indicators and dependence countries from food imports. In view of this, the concepts of financial results and their role in the development of the activities of an agricultural enterprise are disclosed in this article. The relevance of the topic of this study is due to the fact that at this stage of the development of agriculture in the Republic of Belarus, not only a significant amount of state assistance to agricultural enterprises plays an important role, but also an increase in the efficiency of the agricultural enterprises themselves, an increase in their added value and their products.
\end{abstract}

\section{Introduction}

According to the conclusions made by Kushnarenko, Tatyana \& Tabakov, Alexey \& Fomina, Irina \& Khachatryan, Arthur \& Prosandeev, Vladimir \& Oleg, Kholodov. (2019), Marmul ', Larisa. (2018), Borodin, Alex \& Shash, Nataliya \& Tatuev, Arsen \& Galazova, Svetlana \& Rokotyanskaya, Violetta. (2015), agriculture is the most important economic activity that plays a strategic role in the national economy, the main task of which is to ensure the country's food security. In article to Solovei, Nadiya \& Prytula, Kateryna \& Fedorenko, Daryna. (2019), Zinchenko, O.A .. (2010), an important characteristic of agriculture is production limited by the use of land and the natural environment, and it is

\footnotetext{
*Corresponding author: 3701313@mail.ru
} 
land that is the main means of production. Each agricultural enterprise has land plots assigned to it, which it undertakes to use rationally and strive to increase soil fertility.

Bearing in mind the conclusions of Sviatenko, Sergey \& Bogdan, Margarita. (2019), Shcherbyna, V. \& Zubenko, A .. (2018), agriculture is an important sector of the national economy, as it guarantees the food security of the state. According to Baytimerova, A .. (2018), Fesenko, V. \& Vorontsova, L. (2020), agricultural production has specific features and depends on the influence of a number of factors, including natural factors that determine the instability of financial indicators of agricultural enterprises.

In this article, the author postulated the connection of modern conditions of functioning of organizations in the agricultural sector and the need for their study, taking into account the indicator of the formation of financial results HAIDARZHYISKA, Olha \& SHCHEPINA, Tetiana \& MASIUK, Iryna. (2020).

According to Lomova, M. E.. (2019), the financial result of an enterprise is the main factor that affects the size of the profit of an economic entity. Financial results based on the results of activities during the reporting period are determined by analyzing the indicators of financial and economic activity.

Based on the findings of Lomova, M.E.(2019), the financial result of an enterprise is the main factor influencing the size of a business entity's profit. The financial results based on the results of activities during the reporting period are determined by analyzing the indicators of financial and economic activity.

At the same time, researchers Solovei, Nadiya \& Prytula, Kateryna \& Fedorenko, Daryna. (2019), it was determined that the indicators obtained for the purpose of application in management accounting do not always give an objective picture of the enterprise, for the reason that the financial indicators reflected in the financial statements are usually subjective. Its subjectivity is determined primarily by the fact that in tax and accounting, the general value of profit indicators may vary.

Considering the conclusions of Kononenko, Zhanna \& Pestsova-svitalka, Oksana \& Petrenko, Vika. (2019), Poltorak A., Volosyuk Y. (2016), the financial result of an economic entity can be classified:

- the sources of its formation (from the sale of goods, products, from the services provided and work performed);

- the direction of activity of the enterprise (trade, public catering, manufacturing and others);

- the other types of economic activity (statutory, financial and investment);

- by its constituent elements (types of financial result).

\section{Methods}

In the process of conducting this study, the analytical method was used, with the help of which the problems considered in the article were studied in their unity and development. Taking into account the goals and objectives of the study, the structurally functional method of scientific research was also used. This, in turn, made it possible to study the problems associated with the efficient management of an agricultural enterprise in their unity and development.

\section{Results}

This article analyzes the problems of improving the economic efficiency of enterprises in the agricultural sector . External environment (weather conditions, purchase prices for 
products, state regulation of the economy )it has a significant impact on the activities of all agricultural enterprises.

In order to investigate the impact of these problems and the causes of their occurrence, the activity of the CJSC Agrofirm Kolos enterprise was analyzed in this paper.

On the example of this enterprise, it is shown that even enterprises that work profitably face problems that they cannot solve themselves.

Other agricultural enterprises, in our opinion, have similar problems,

because the external environment in which they operate is largely the same.

Therefore, in this paper, the results can be generalized for other enterprises.

In our opinion, the problem of rural development has not yet been sufficiently studied in the scientific literature.

Many researchers believe that to solve it, it is necessary first of all to open the land market. The government also takes this view.

It believes that the new owners will be able to solve most of the problems of the village without the help of the state. However, in our country, about $1 / 3$ of the population lives in rural areas.

The sale of land will attract investment, but it will not solve the problems of people living in villages, because the social infrastructure is very worn out, there are not enough schools and hospitals.

In our opinion, to solve all the problems of rural development, we need a comprehensive approach based on the correct state policy.

Let us analyze the formation of financial results at CJSC Agrofirm Kolos based on studying not only the final result of the financial and economic activities of the enterprise, but also the process of its formation. The leading indicator on which the enterprise is guided in its activities is profit. The financial results of CJSC Agrofirm Kolos for the analyzed period are presented in table 1 .

Table 1. Analysis of the financial results of CJSC Agrofirm Kolos for 2017-2019

\begin{tabular}{|c|c|c|c|c|c|}
\hline \multirow{2}{*}{$\begin{array}{c}\text { Indicators, } \\
\text { in thousand Belarusian roubles } \\
\text { (tsd BR) }\end{array}$} & \multirow[b]{2}{*}{2017} & \multirow[b]{2}{*}{2018.} & \multirow[b]{2}{*}{2019} & \multicolumn{2}{|c|}{ Changes $(-/+)$} \\
\hline & & & & $\begin{array}{l}2018- \\
2017\end{array}$ & $\begin{array}{l}2019- \\
2018\end{array}$ \\
\hline Revenues & 293316 & 297962 & 329790 & 4646 & 31828 \\
\hline Volume of sales & 253148 & 265270 & 295673 & 12112 & 30401 \\
\hline Gross margin or loss & 40168 & 32692 & 34117 & -7476 & -1425 \\
\hline Margin or losses from sales & 40112 & 32511 & 34066 & -7601 & 1555 \\
\hline Other income & 6344 & 27357 & 39117 & 21013 & 11760 \\
\hline Other expenses & 7635 & 12698 & 25640 & 5063 & 12942 \\
\hline Profit or loss before tax & 19007 & 24544 & 21734 & 5537 & -2810 \\
\hline Current income tax & 273 & 356 & 364 & 83 & 8 \\
\hline Net profit or loss & 18734 & 24187 & 21366 & 5453 & -2821 \\
\hline Profitability of sale, per cent & 6,39 & 8,12 & 6,48 & 1,73 & $-1,64$ \\
\hline
\end{tabular}

As can be seen from the indicators in table 1, in 2018 the size of revenues from the sale of finished products at CJSC Agrofirm Kolos increased by 4646 tsd BR and reached 297962 tsd BR, and in 2019 its value has already reached 329,790 tsd BR, i.e. 31828 tsd $\mathrm{BR}$ more in relation to the previous reporting period.

The volume of sales increased throughout the analyzed period for 2018, 2019. So in 2018, it amounted to 265270 tsd BR, which in turn is for 12112 tsd BR exceeds the indicator of 2017, and in 2019 increased to 295673 tsd BR, i.e. even more by 30401 tsd BR, compared with 2019. 
Margin from sales of finished products in 2018 decreased by 7601 tsd BR in relation to 2017 and reached the value of 27357 tsd BR, and in 2019 amounted to 34066 tsd BR, which is 1555 tsd BR more than the level of 2018.

In 2018, the amount of net profit increased by 5453 tsd BR compared with 2017 and amounted to 24187 tsd BR, in 2019 the net profit of this agricultural enterprise was 21366 tsd BR, which is almost 2821 tsd BR lower than in 2019.

\section{Discussion}

Thus, the financial result of the activities of CJSC Agrofirm Kolos decreased. Despite the fact that the revenue of CJSC Agrofirm Kolos increases annually, the net profit of the enterprise decreased. According to the table. 1, this is due to an indicator of cost growth.

So, if in 2019 the company's revenue grew by 10.68 per cent compared to the level of 2018 , then the cost price increased by 11.46 per cent. The increase in prime cost is associated with an increase in purchase prices for the resources used, costs for storage and transportation of finished products, adverse weather conditions, costs for maintaining vehicles and equipment, etc.

At the same time, the company was forced to increase the value of final products to cover the costs incurred by the company, which is not always an indicator of competitiveness.

As a result, we can conclude that the products are sold at prices of the level of the previous year, despite the fact that the company already incurred more expenditure this year.

The reduction in profit leads to the fact that the company invests less in its development is not able to timely update equipment and cannot afford to expand its activities and range of products. Considering that the majority of agricultural enterprises are in a state of decline and have heavily worn-out fixed assets, they have practically no opportunity to correct the situation on their own.

In our opinion, the solution to this problem should, first of all, be undertaken at the state level. In order to counter threats to economic security, state authorities and local selfgovernment in cooperation with civil society institutions should implement a state socioeconomic policy that provides for the implementation of rational import substitution, accelerating the development of the agro-industrial complex to ensure food security.

Significant levers to support the activities of agricultural producers in times of crisis due to unfavorable market conditions, economic sanctions and falling solvency of the population, in our opinion, should be the corresponding state program to support domestic producers of agricultural products. Which, in turn, should provide for state subsidies for livestock and seed breeding, soft loans for the purchase of the latest agricultural equipment, improving living standards in rural areas, etc.

In our opinion, in the current global financial crisis, there is a need to identify additional economic instruments to support agro-industrial enterprises and state regulation of their economic activities.

An important tool used to regulate financial relations may be the creation of regional funds to support agro-industrial enterprises.

The low level of financial security of organizations, the violation of stability in financial relations negatively affect the stability of reproduction processes in agriculture, and in the whole, on the entire food complex. These adverse economic events in certain periods, especially in years with often repeated negative climatic processes (drought, floods and frosts), greatly complicate the overall economic situation in the country.

The experience of leading enterprises shows that only with the organization of selfsupporting market relations, material support of collectives and agricultural units, as well as 
each employee of these enterprises, it is possible to achieve a gradual increase in production, improve its quality, rational use of monetary and material resources and increase the profitability of products for food security.

The Republic of Belarus has enormous potential for the production of agricultural products, including for export, for achieving food security, and for the steady growth of the agro-industrial sector of the economy in the medium and long term.

In the framework of this work, by studying the characteristics of the functioning of agricultural enterprises, it was noted that the level of profitability of production largely depends on state and regional programs in agriculture, and primarily their investment efficiency.

\section{Conclusions}

Towards the desired goal, more attention should be paid to investing in various innovative projects, involving public and private investments, on the way to achieving stable growth in the agribusiness sector of the economy.

The availability of reserves for agricultural enterprises to increase profitability and profit makes it possible to increase production volumes, introduce innovative technologies, improve living standards and reduce unemployment in agriculture.

The results obtained in this work, in our opinion, can be taken into account in the development of state and regional programs for rural development. We believe that revenues from land privatization without the development of social infrastructure in rural areas will not be able to solve the problem of improving the efficiency of agricultural production. And the development of social infrastructure is impossible without the state.

\section{References}

1. A. Baytimerova, Business Strategies, 5, 11 (2018)

2. P. Gadgieva, Financial Result: Transformation of the Concept, Auditor, 1, 45 (2015)

3. Alex Borodin, Nataliya Shash, Arsen Tatuev, Svetlana Galazova, Violetta Rokotyanskaya, Mediterranean Journal of Social Sciences, 6(4), 572 (2015)

4. V. Fesenko, L. Vorontsova, Efficient economy, 1, 3 (2020)

5. Olha Haidarzhyiska, Tetiana Shchepina, Iryna Masiuk, Economics, Finances, Law, 3(1), 24 (2020)

6. Zhanna Kononenko, Oksana Pestsova-Svitalka, Vika Petrenko, Market Infrastructure, 36, 27 (2019)

7. Tatyana Kushnarenko, Alexey Tabakov, Irina Fomina, Arthur Khachatryan, Vladimir Prosandeev, Kholodov Oleg, IOP Conference Series: Earth and Environmental Science, 403(1), 012074 (2019)

8. M.E. Lomova, Scientific Development Trends and Education, 57, 96 (2019)

9. Larisa Marmul', University Economic Bulletin, 39, 144 (2018)

10. A. Poltorak, Y. Volosyuk Economic Annals-XXI, 158(3-4(2)), 35 (2016)

11. V. Shcherbyna, A. Zubenko, Development of Management and Entrepreneurship Methods on Transport (ONMU), 3, 23 (2018)

12. Nadiya Solovei, Kateryna Prytula, Daryna Fedorenko, Internauka, 2, 50 (2019)

13. Sergey Sviatenko, Margarita Bogdan, Eastern Europe: economy, business and management, 6(23), 385 (2019) 
14. O.A. Zinchenko, Actual Problems of Economics, 109 (2010) 